\title{
CHARACTERIZATION OF SOME NEW OLIVE OIL GENOTYPES GROWING IN EL-KHATATBA ZONE - EGYPT
}

\author{
MOUNIR M. EID ${ }^{1}$ and MOHAMMAD M. EL-SAYED ${ }^{2}$ \\ 1- Oils and Fats Dept, Food Tech. Res. Inst., A RC, Giza, Egypt. \\ 2- Olive and Semiarid Zone Fruits Dept., Horticulture. Res. Inst., A R C, Giza, Egypt.
}

(Manuscript received 31 December 2012 )

\begin{abstract}
This investigation was aimed to characterize virgin olive oil from four olive oil cultivars (Koroniki, Arbequina and new cultivars No.1 and No.138) cultivated in El-Khatatba zone, Egypt during two successive seasons 2010/2011 and 2011/2012. The quality indices (Free acidity , Peroxide value, K232, K270 and $\Delta \mathrm{K}$ moreover, the fatty acids, minor components beside oxidative stability and sterol composition of the obtained olive oils (VOO) were analyzed to obtain a more complete characterization of these varietal oils. Results revealed that, all the analyzed VOOs were classified into "Extra virgin" category according to the regulated physicochemical parameters. In addition, Koroniki olive oil cultivar was the only one complied with IOC, 2011(Trade Standard for Olive Oil) during evaluation period if fatty acid and sterols compositions were taken into account and it represented the highest oxidative stability during the two seasons ( 24.81 and $26.5 \mathrm{hr}$ at the 1st and 2nd seasons, respectively) while, Arbequina cultivar was the lowest one $(9.80$ and $12.99 \mathrm{hr}$ at the 1st and 2nd seasons, respectively) which, attributed to the content of minor components (polyphenols, atocopherols, chlorpphyll and carotenoids) and monounsaturated fatty acid. Also, the main sterols found in Koroniki VOO were $\beta$-sitosterol ( 82.10 and 83.33 at the 1st and 2nd seasons, respectively) , $\Delta 5$-avenasterol, campesterol and stigmasterol. The new cultivar No.1 or No.138 had the highest mean oil contents (20.25 and $18.75 \%$, respectively) and good oxidative stability virgin olive oil but they, were stood out of IOC limits during evaluation period due to its non-compliance in fatty acid composition. The minor components, fatty acids and sterol compositions are mainly affected by olive cultivars (genotype) and climatic conditions.

Keywords: New olive oil cultivars, olive oil quality, minor components, fatty acids, sterols .
\end{abstract}




\section{INTRODUCTION}

The olive tree (Olea europaea) has an important social and economical significance in the Mediterranean basin, which occupies $98 \%$ of the world's cultivated olive trees (Alfonso and Owen, 2002). Olive oil is one of the oldest known vegetable oils mainly produced in the countries surrounding the Mediterranean Sea. It is a natural fruit juice, obtained from the fruit of tree Olea europaea L., with a unique composition and quality. Olive oil is one of the very few oils that can be consumed in its natural form, thus preserving all its natural constituents. Several methods of analysis have been proposed and are affected by several factors, including packaging (Kiritsakis, 1998).

The consumption of extra virgin olive oil, the most characteristic component of the Mediterranean diet, is currently increasing because of its nutritional and healthpromoting effects, which have been related to the optimal balance between saturated, monounsaturated (MUFA), and polyunsaturated fatty acids (PUFA), as well as to minor components such as sterols, chlorophyll, polyphenols and tocopherols (Cercaci, et. al., 2007 and Lazzez et. al., 2008) .

The chemical composition and quality of virgin olive oil are influenced by a variety of factors, among them geographical production area (altitude and soil composition), climatic conditions prevailing in the production year, cultivar, and extraction process, Baccouri et. al., 2007 and Dag et. al., 2009, harvesting time. All of these parameters influence fruit firmness, ease of oil extraction and sensory characteristics Menz and Vriesekoop, 2010. The composition of fatty acids, and the levels of polyphenols, tocopherols, sterols and pigment. The magnitude of these changes depends on the cultivar, climate and growing conditions. The changes are reflected in the quality grade, sensory characteristics, oxidative stability and nutritional value of the product. These differences are the "added-value" offerd by the protected designation of origin (PDO) Lopez-feria et. al., 2008 and Koprivnjak et. al., 2009.

Olive oil is mainly made up of triglycerides (more than $98 \%$ ), whereas the unsaponifiable fraction of virgin olive oil (VOO) represents $1-2 \%$ of the oil. This fraction is made up of minor constituents, which may vary both qualitatively and quantitatively depending on vegetal species, climatic conditions, extraction and refining procedures, and storage conditions (Canabate-Diaz et. al., 2007). These also greatly influence the organoleptic quality and stability of the oil. voO may contain up to $0.7 \%$ hydrocarbons, which is mainly constituted by squalene, a precursor of other sterols and triterpenic alcohols (Bortolomeazzi, et. al., 2001). Besides squalene, the 
hydrocarbon fraction of olive oil comprises of low quantities of epoxy-squalene isomers and alkanes (C16-C35).

The nutritional quality of virgin olive oil has been related to its composition, in particular the high concentration of oleic acid, which accounts for about $55-83 \%$ of the total fatty acids (Codex Alimentarius and IOC). This monounsaturated fatty acid favours the reduction of LDL cholesterol and is related to the prevention of cardiovascular diseases.

Virgin olive oil (VOO) nutritional quality has also been associated with its minor components, mainly antioxidants such as tocopherols (chiefly a-tocopherol) and polar phenols, but also sterols (mainly $\beta$-sitosterol), and pigments (chlorophylls, carotenoids), which also play a role in the stability of the oil and the prevention of cardiovascular diseases, tumors and degenerative diseases of aging (Visioli \& Galli, 2002). Minor compounds are of great importance in the final composition of olive oil because they influence the stability and overall acceptability as well as the nutritional and health related properties of the olive oil. Compounds such as sterols, squalene, and tocopherols are of great interest as high value added products because of their nutraceutical activities (Ibaneza et. al., 2002).

Fatty acids and Sterols are nutritionally important lipids that need to be routinely determined in foods. In olive oil, content and composition of fatty acids and sterols can vary due to the agronomic and climatic conditions, fruit or seed quality, oil extraction and refining procedures and storage conditions Plant sterols or phytosterols make up the main part of the unsaponifiable fraction of olive oil. The International Olive Council (IOC) imposes limits or ranges for each type of fatty acids and sterol based on the natural levels found in traditional olive oil types. Fatty acids and sterol profiles outside these ranges could suggest that the olive oil is not genuine.

New cultivars today are required to adopt for the olive oil industry to suit with modern intensive mechanized orchards. Narrow erect trees for mechanical harvesting, adaptability to irrigation, uniform maturation, minimal alternate bearing, and resistance to leaf and root diseases are the goals of most present olive breeding program. The development of new olive products and freezing resistance are also considered ( Dabbous, et. al., 2010)

The aim of this study was to evaluate the effect of geographical area and different cultivars (Koroniki, Arbequina, and new cultivars No.1 and No.138 which are growing in El-Khatatba zone, Egypt) during two consecutive harvesting seasons on the characteristics of produced virgin olive oil, quality indices, minor components, sterols and fatty acid composition. 


\section{MATERIALS AND METHODS}

\section{Materials}

\section{Source of virgin olive Oils samples}

Olive's fruits (Koroniki, Arbequina, and new cultivars No.1 and No.138) were harvested during seasons of 2010/2011 and 2011/2012 from research olive orchards in El-Khtatba zone, Egypt. Koroniki and Arbequina cultivars are well known cultivars originated from Greece and Spain and they are growing under Egyptian conditions in different areas. The new cultivar No.1 produced from the open pollination of Arbequina cultivar and $c V$ No. 138 produced from pollination of Arbequina $\mathrm{X}$ Hamed cultivars. The harvesting date was at the first of November. The oil was immediately extracted by means of the continuous extraction system two-phases in Agricultural Research Center. The oil percent was calculated on fresh weight basis directly after oil extraction. The samples were then kept in dark glasses at $-18{ }^{\circ} \mathrm{C}$, until analysis.

\section{Analytical Methods}

\section{physicochemical and Quality indices of virgin olive oil}

Quality parameters (free acidity, peroxide value and UV absorption characteristic, $\mathrm{K}_{232}, \mathrm{~K}_{270}$, and $\Delta \mathrm{K}$ ), were carried out, following the analytical methods described by Regulation EEC/2568/91 of the Commission of the European Union (EEC, 1991). Unsaponifaible matter percent was determined using AOAC (2005).

Free acidity, given as \% of oleic acid. Peroxide value, expressed in milliequivalents of active oxygen per $\mathrm{kg}$ of oil (meq/ $\mathrm{kg}$ ).

$\mathrm{K}_{270}$ and $\mathrm{K}_{232}$ extinction coefficients were calculated from absorbance at 270 and $232 \mathrm{~nm}$, respectively, with a UV spectrophotometer (JENWAY 6405 UV/Vis .Spectrophotometer, England) using a $1 \%$ solution of oil in cyclohexane and a path length of $1 \mathrm{~cm}$.

\section{Oxidative stability}

Oxidative stability was evaluated by the Rancimat method (Gutierrez et. al., 2002). Stability was expressed as the induction time (hours), measured with the Rancimat 679 apparatus (Metrohm Co., Switzerland), using an oil sample of $5 \mathrm{~g}$ heated to $100^{\circ} \mathrm{C}$ and air flow of $20 \mathrm{~L} / \mathrm{h}$

\section{Minor components determination}

\section{A- Total phenols}

Olive oil samples were extracted three times with $10 \mathrm{ml}$ of a methanol/water mixture $(60: 40 \mathrm{~V} / \mathrm{V})$. The pooled extracts were washed with $10 \mathrm{ml}$ of $\mathrm{n}$-hexane and solvents were removed with a rotary evaporator. Total phenols (TP) content of the methanolic extract of olive oil were calorimetrically determined using the Folin- 
Ciocalteu method (Gamez-Meza et. al., 1999) where an aliquot (1 ml) of methanolic extract was mixed with diluted ethanol amine $(1 \mathrm{ml})$ at room temperature. After $5 \mathrm{~min}$ the absorbance was measured at $750 \mathrm{~nm}$ using a spectrophotometer (JENWAY 6405 UV/Vis., England).Results were expressed as caffiec acid.

\section{B- Total Tocopherols}

The total tocopherols content was determined in virgin olive oils samples according to the method of Wong et. al., (1991). Result were expressed as atocopherols $(\mathrm{mg} / \mathrm{kg})$.

\section{C- Chlorophyll and carotenoids pigments}

Oil $(7.5 \mathrm{~g})$ was accurately weighed and dissolved in cyclohexane up to a final volume of $25 \mathrm{ml}$. Chlorophyll and carotenoids were then determined by their absorption at 670 and $472 \mathrm{~nm}$, respectively, using a spectrophotometer (JENWAY 6405 UV/Vis., England) Minguez-Mosquera et. al., (1991). Results were expressed ( $\mathrm{mg} / \mathrm{kg}$ oil) as pheophytin and $\beta$-carotene for chlorophyll and carotenoids, respectively.

\section{Gas chomatography analysis \\ Methylation of fatty acids}

An aliquot of fatty acids, about $10 \mathrm{mg}$, was dissolved in $2 \mathrm{ml}$ hexane and then $0.4 \mathrm{ml}$ of $2 \mathrm{~N} \mathrm{KOH}$ in anhydrous methanol was added (Cossignani et. al., 2005), after 3 $\mathrm{min}, 3 \mathrm{ml}$ water was added. The organic layer, separated by centrifugation, was dried over anhydrous sodium sulfate, and then concentrated, with a $\mathrm{N}_{2}$ stream to around $0.5 \mathrm{ml}$ for GC analysis of fatty acids methyl esters (FAME) as described below.

\section{GC analysis of FAME}

Agilent 6890 series GC apparatus provided with a DB-23 column $(60 \mathrm{~m} \times$ $0.32 \mathrm{~mm} \times 0.25 \mu \mathrm{m}$ ) was used. Oven temperatures were $150^{\circ} \mathrm{C}$ ramped to $195^{\circ} \mathrm{C}$ at $5^{\circ} \mathrm{C} \min ^{-1}$, ramped to $220^{\circ} \mathrm{C}$ at $10^{\circ} \mathrm{C} \min ^{-1}$ and flow rate was $1.5 \mathrm{~min}^{-1}$. Fatty acids results after the previous procedures steps were transformed into methyl esters and directly injected into the GC.

\section{sterols composition}

A sample of 5 grams oil was dissolved in $3 \mathrm{ml}$ of hexane. The mixture was saponified with sodium hydroxide solution in methanol $(2 \mathrm{~N})$ at water bath for 1-2 $\mathrm{h}$. Then, unsaponifaible matters were extracted. Then $1 \mu 1$ of the sample was injected into a Agilent 6890 series GC apparatus (setup:DB-5 capillary column, $\mathrm{A} \mathrm{N}_{2}$ carrier gas at $0.9 \mathrm{ml} \mathrm{min}{ }^{-1}$ constant flow rate, split/splitless injector at $230^{\circ} \mathrm{C}$ in the splitless mode. Oven temperature: $50^{\circ} \mathrm{C}$ holds for $2 \mathrm{~min}$, ramped to $230^{\circ} \mathrm{C}$ at $15^{\circ} \mathrm{C} \mathrm{min}{ }^{-1}$, 
ramped to $310^{\circ} \mathrm{C}$ at $3^{\circ} \mathrm{C} \mathrm{min}^{-1}$ hold for $10 \mathrm{~min}$. The relative percent of each sterol was calculated using GC Chemstation software (Szterk et. al., 2010).

\section{RESULTS AND DISCUSSION}

The chemical composition of virgin olive oils may be influenced by genotype, and different agronomic, environmental and technological factors Dag et. al., 2009, therefore we studied the effect of geographical area and different cultivars (genotypes) (Koroniki, Arbequina, and new cultivars No.1 and No.138 which were growing in El-Khatatba zone, Egypt) during two consecutive harvesting seasons on the characteristics of produced virgin olive oil, quality indices, minor components, sterols and fatty acid composition.

\section{Olive oil quality}

Table 1 shows the changes in quality parameters, the \% free fatty acids (FFA) as oleic acid, Peroxide values meq $\mathrm{O}_{2} / \mathrm{kg}$ oil , Ultra violet absorbency and oil content of the oils obtained from olive oil cultivars during two successive seasons. The FFA values of the oils from all different cultivars were lower than $0.8 \%$, which is met the limits set for 'extra' virgin olive oil quality in IOC, Trade Standard for Olive Oil (2011). The acidity values in crs Arbequina and No.1 were increased in the second harvesting time, however, they were approximately the same in the other two cultivars. These changes in FFA may be due to not follow the same good manufactures practices during extraction process or changes in climatic conditions.

The peroxide value (PV) is a measure of primary oxidation process. The PV of the oils was measured immediately after the harvesting time. The highest PV values were observed in oils obtained from $c V$ No.1 in the second harvesting season and in

CV No.138 in the first whereas, the lowest PV was observed in Arbequina cultivar. None of the oils analyzed exceeded the maximum peroxide value for extra virgin olive oil limits (20 meq $\mathrm{O}_{2} / \mathrm{kg}$ ), which established by IOC, Trade Standard for Olive Oil 2011. 
Table 1. Quality characteristics of olive oil cultivars during two consecutive seasons

\begin{tabular}{|c|c|c|c|c|c|c|c|c|}
\hline \multirow{2}{*}{ Characteristics } & \multicolumn{2}{|c|}{ Koroniki } & \multicolumn{2}{|c|}{ Arbequina } & \multicolumn{2}{|c|}{1} & \multicolumn{2}{|c|}{138} \\
\hline & $2010 / 2011$ & 2011/2012 & 2010/2011 & 2011/2012 & $2010 / 2011$ & 2011/2012 & $2010 / 2011$ & $2011 / 2012$ \\
\hline $\begin{array}{c}\% \text { FFA } \\
\text { (as Oleic acid) }\end{array}$ & 0.78 & 0.75 & 0.52 & 0.80 & 0.28 & 0.61 & 0.41 & 0.42 \\
\hline $\begin{array}{l}\text { Peroxide value } \\
\text { (meq } \mathrm{O}_{2} / \mathrm{kg} \text { oil) }\end{array}$ & 6.33 & 8 & 4.47 & 8 & 4.20 & 10.11 & 10.04 & 7.78 \\
\hline$K_{232}$ & 1.62 & 1.13 & 1.91 & 1.47 & 1.52 & 1.19 & 0.89 & 1.99 \\
\hline$K_{270}$ & 0.11 & 0.08 & 0.17 & 0.12 & 0.10 & 0.08 & 0.06 & 0.14 \\
\hline$\Delta \mathbf{k}$ & 0.003 & 0.001 & 0.0005 & 0.003 & 0.002 & 0.002 & 0.003 & 0.002 \\
\hline $\begin{array}{l}\text { Oil content } \\
\text { (\% Fresh } \\
\text { weighbasis) }\end{array}$ & 17 & 16.50 & 18.44 & 19 & 20.5 & 20 & 18 & 19.50 \\
\hline
\end{tabular}

Regarding to $\mathrm{K}_{232}$ and $\mathrm{K}_{270}$ (Second oxidation index) are mainly indicating the conjugation of trienes and also of the presence of carbonylic compounds. The maximum permitted values of $\mathrm{K}_{232}, \mathrm{~K}_{270}$ and $\Delta \mathrm{K}$ for extra virgin olive oils are 2.50, 0.22 and $\geq 0.01$ respectively (IOC, 2011). Table (1) shows the changes in $K_{232}, K_{270}$ and $\Delta K$ of oils obtained from olives oil cultivars at the two successive seasons. Results revealed for $K_{232}, K_{270}$ and $\Delta K$ values for all cultivars were not exceeded the limits established by IOC, 2011 which mean that the low values for quality indices of the obtained oils including the two new cultivars (No.1 and No.138) were classified into" Extra virgin" olive oil. These results are in agreement with the results obtained by Eid et. al., 2012 for Koroniki and Arbequina cultivars which cultivated in Giza zone.

Concerning to oil content, results showed that, the highest oil content was found in the two successive season in $c V$ No.1 (20.5 and 20\%) and $c V$ No. 138 (18 and $19.5 \%$ ) compared with Arbequina (18.44 and 19\%) and the lowest oil content was found in Koroniki cultivar (17 and 16.50\%). The chemical composition and quality of virgin olive oil are influenced by a variety of factors, among them geographical production area (altitude and soil composition), climatic conditions prevailing in the production year, cultivar, and extraction process ( Baccouri et. al., 2007 and Dag et. al., 2009)

\section{Minor components and oxidative stability of olive oil cultivars}

Table (2) shows the minor components (polyphenols, tocopherols, chlorophyll and carotenoids) of the olive oils cultivars. The bioactive components of 
extra virgin olive oil are result of a number of variables acting before extraction (such as variety, environmental , climatic, soil and cultivation conditions , olive ripeness and olive healthy) and during olive oil extraction and storage ( Velasco and Dobarganes, 2002). The total phenolic compound in the virgin olive oil of the four varieties showing higher values in the $c V$ no.138 (174.20 ppm in the first season) and $c V$ No.1 (115.6 ppm in the second season) however, oil extracted from Arbequina variety had the lowest values (60.4 and $90.7 \mathrm{ppm}$ ). The same results for Arbequinat variety had obtained by Eid et. al., 2012 when compared with Coratina, Koroniki and Siwi cultivars which cultivated in Giza zone. Extra-virgin olive oil contains a considerable amount of phenolic compounds that are responsible for its peculiar taste and for its high stability. Recent findings demonstrate that olive oil phenolics are powerful antioxidants, both in vitro and in vivo, and possess other potent biological activities that could partially account for the observed healthful effects of the Mediterranean diet (Visioli \& Galli, 2002).

Table 2. Minor components ( $\mathrm{mg} / \mathrm{kg}$ oil) and oxidative stability of olive oil cultivars during two consecutive seasons

\begin{tabular}{|c|c|c|c|c|c|c|c|c|}
\hline \multirow{2}{*}{$\begin{array}{c}\text { Characteristics } \\
(\mathrm{mg} / \mathrm{kg})\end{array}$} & \multicolumn{2}{|c|}{ Koroniki } & \multicolumn{2}{|c|}{ Arbequina } & \multicolumn{2}{|c|}{1} & \multicolumn{2}{|c|}{138} \\
\hline & $2010 / 2011$ & $2011 / 2012$ & $2010 / 2011$ & $2011 / 2012$ & $2010 / 2011$ & $2011 / 2012$ & $2010 / 2011$ & $2011 / 2012$ \\
\hline $\begin{array}{c}\text { Total poly- } \\
\text { phenols } \\
\end{array}$ & 71.7 & 109.8 & 60.40 & 90.7 & 86.40 & 115.6 & 174.20 & 122.1 \\
\hline $\begin{array}{c}\text { Total } \\
\text { Tocopherols }\end{array}$ & 115.60 & 140.20 & 121.32 & 133.60 & 44.66 & 112.40 & 290.82 & 107.30 \\
\hline Chlorophyl I & 3.28 & 3.01 & 1.20 & 1.61 & 2.40 & 7.45 & 0.84 & 2.18 \\
\hline Carotenoids & 18.20 & 21.25 & 15.50 & 16.08 & 5.56 & 3.37 & 4.20 & 7.46 \\
\hline $\begin{array}{l}\text { *Oxidative } \\
\text { stability (h) }\end{array}$ & 24.81 & 26.50 & 9.80 & 12.99 & 15.50 & 20.40 & 17.68 & 13.70 \\
\hline
\end{tabular}

*Oxidative stability was determined using Rancimat Methods at $100^{\circ} \mathrm{C}$.

The tocopherols content of virgin olive oil are important to protect lipids against autoxidation and thereby to increase its storage life and value as some whole life food. The a-tocopherol content varied among $44.66 \mathrm{ppm}$ in $c v$ No.1 in first season and $290.82 \mathrm{ppm}$ in cultivar 138. Results showed fluctuation in the values of atocopherols and polyphones in the two successive seasons, these may be due to affect by varieties and climatic conditions also, the antioxidant activity of these substances during the autoxidation process especially in the early stage of oxidation also, carotene and a-tocopherols may undergo similar oxidative modification with loss of vitamin activity and color, and thus of nutritive value Gutierrez et. al., 2002. 
The total pigments content of olive oils is an important quality parameter because it correlates with color, which is a basic attribute for evaluating olive oil quality. Furthermore, pigments are also, involved in autoxidation and photooxidation mechanisms (Minguez-Mosquera et. al., 1991). They have also demonstrated that chlorophyll act as prooxidant under light storage ,whereas $\beta$-carotene minimizing lipid oxidation by its light filtering effect. Pigment content varied from 2.18 ppm ( $c V$ No.138 in $2^{\text {nd }}$ season) and 7.45 ( $\mathrm{cv}$ No.1in $2^{\text {nd }}$ season). On the other hand, the $\beta$ - carotenen content had the highest values for Koroniki (21.25 ppm) and Arbequina (16.08 ppm) cultivars in the second season, respectively.

With respect to oxidative stability Data in Table 2 shows that Koroniki olive oil cultivar had the highest oxidative stability (24.81 and $26.50 \mathrm{hr}$ in the first and second seasons, respectively) among the other varieties. However, Arbquaina cultivar had the lowest oxidative stability during the first and second season (9.80 and $12.99 \mathrm{~h}$ and for CV NO.138 and No.1 the oxidative stability come in between the two abovementioned cultivars. These results are in agreement with the result of Eid et. al., 2012 for Koroniki and Arbequina cultivars which cultivated in Giza zone. In addition, One can conclude from result (Table 2) that the oxidative stability increased in the second season with the increase of bioactive components mostly with total polyphenols, atocopherols and $\beta$-carotene for Koroniki, Arbequina and No. 1 cultivars, respectively and vice versa with $c v$ No. 138 which mean the direct proportion correlation between the oxidative stability and bioactive component Basuny et. al., (2008) had found correlation between stability and the bioactive components and the quality indices and their results indicated that the compound most related to oxidative stability were the phenolic compounds and pigments. The fatty acids of virgin olive oil are mainly monounsaturated (Table 3), these fact and the presence of tocopherol, carotenoids , pigments compounds make virgin olive oil more stable than other oils Gutierreez et. al., 2002.

\section{Fatty acid profiles}

The fatty acids profile for olive oil cultivars in El-Khataba region during the two seasons beside, total saturated fatty acids (SFA), polyunsaturated fatty acids (PUFA), monounsaturated fatty acids (MUFA), and MUFA/PUFA ratio are shown in Table 3.

The distribution of fatty acid composition revealed that the highest content of palmitic acid as saturated fatty acid (22.07\% in the first season) was found in Arbequina VOO. The palmitoleic acid content was also higher in Arbequina VOO (4.49\% in the second season) than in the others cultivars. The above-mentioned values for palmitic and palmitoleic are considered out accepted limits of IOC, 2011 
(palmitic 7.5 - 20 and palmitoleic $0.3-3.5 \%$ ) for olive oil. The oleic (which has great importance because of their nutritional implication and effect on oxidative stability of oil) and linoleic acids (which is susceptible to oxidation) contents were the most useful and significant parameters for differentiating varieties, only Koroniki cultivar had highest accepted oleic value in the two seasons as established by IOC, 2011 (55-83\%) followed by $c v$ No.1 only in the second season which had the nearly boarder limits (57.88\%) of oleic acid compared with $C V$ Arbequina (44.14 and $45.37 \%$ ) which had the lowest oleic content, and also $c v$ No.1 in the first season and No.138 in both seasons. . whereas the highest linoleic acid was found in $C V$ No.138 (28.64 and $31.08 \%$ in the first and second seasons, respectively) followed by Arbequina VoO (25.99\%) and $c v$ No.1 (24.91\% in the 1st season) these values out of the accepted range stated by IOC,2011 for linoleic acid (3.5 -21\%). Also, high linolenic acid contents were shown by $c V$ s No.138 and Arbequina, VOO they were out of accepted limits established by IOC, 2011 for linolenic acid $(\leq 1 \%)$ and it seemed to contribute to their low oxidative stability, since this leads to a low mono/polyunsaturated ratio (Beltran, 2000).

One can conclude that, Koroniki varietiy produced oils with excellent fatty acid (FA) composition, i.e., a high level of oleic acid, low palmitic and linoleic acid content which is accepted against IOC, 2011(Trade Standard for Olive Oil) followed by $c V$ No. 1 only in 2nd season which mean that it need more evaluation for many next seasons .

Also, evaluation in different zone areas to enhancement the fatty acid profile or to ensure the stability of fatty acids profile. However, Arbequina and $C V$ NO. 138 VOO was found to be out of the legal ranges stated by the IOC for fatty acids (IOC, 2011). These results are in agreement with Eid et. al., 2012 for Koroniki and Arbequina varieties which cultivated in Giza zone. The fatty acids compositions has relatively wide range due to the genetic and climatic environmental factors Lopez-feria et. al., 2008 and Koprivnjak et. al., 2009. 
Table 3. Fatty acids composition of olive oil cultivars during two consecutive seasons

\begin{tabular}{|c|c|c|c|c|c|c|c|c|}
\hline \multirow{2}{*}{$\begin{array}{l}\text { Fatty } \\
\text { acid }\end{array}$} & \multicolumn{2}{|c|}{ Koroniki } & \multicolumn{2}{|c|}{ Arbequina } & \multicolumn{2}{|c|}{1} & \multicolumn{2}{|c|}{138} \\
\hline & $2010 / 2011$ & $2011 / 2012$ & $2010 / 2011$ & $2011 / 2012$ & $2010 / 2011$ & $2011 / 2012$ & $2010 / 2011$ & $2011 / 2012$ \\
\hline$C_{16: 0}$ & 15 & 12.45 & 22.07 & 21.58 & 18.53 & 16.21 & 16.30 & 14.54 \\
\hline$C_{16: 1}$ & 1.24 & 1.04 & 3.77 & 4.49 & 2.36 & 1.78 & 1.51 & 1.35 \\
\hline$C_{17: 0}$ & 0.04 & 0.06 & 0.15 & 0.20 & 0.12 & 0.14 & 0.04 & 0.05 \\
\hline$C_{17: 1}$ & 0.07 & 0.10 & 0.20 & 0.25 & 0.20 & 0.23 & 0.06 & 0.07 \\
\hline$C_{18: 0}$ & 2.47 & 2.50 & 1.79 & 1.62 & 2.43 & 2.41 & 1.85 & 1.92 \\
\hline$C_{18: 1}$ & 68.18 & 73.06 & 44.14 & 45.37 & 49.77 & 57.88 & 49.39 & 48.99 \\
\hline$C_{18: 2}$ & 10.92 & 8.12 & 25.99 & 24.40 & 24.91 & 19.23 & 28.64 & 31.03 \\
\hline $\mathrm{C}_{18: 3}$ & 0.95 & 0.90 & 1.06 & 1.17 & 0.75 & 0.83 & 1.21 & 1.10 \\
\hline $\mathrm{C}_{20: 0}$ & 0.51 & 0.57 & 0.38 & 0.43 & 0.47 & 0.51 & 0.42 & 0.40 \\
\hline$C_{20: 1}$ & 0.36 & 0.43 & 0.22 & 0.26 & 0.22 & 0.27 & 0.37 & 0.40 \\
\hline $\mathrm{C}_{22: 0}$ & 0.14 & 0.15 & 0.11 & 0.09 & 0.12 & 0.14 & 0.09 & $\mathrm{Nd}$ \\
\hline$C_{24: 0}$ & 0.07 & 0.56 & 0.07 & 0.11 & 0.06 & 0.34 & 0.06 & 0.12 \\
\hline$\Sigma$ SFA & 18.23 & 16.22 & 24.57 & 16.94 & 21.73 & 19.75 & 18.76 & 17.03 \\
\hline$\Sigma$ USFA & 81.69 & 83.65 & 75.38 & 75.94 & 78.21 & 80.16 & 81.18 & 82.94 \\
\hline MUSFA & 69.58 & 74.63 & 48.33 & 50.37 & 52.55 & 60.16 & 51.33 & 50.81 \\
\hline PUSFA & 11.87 & 9.02 & 27.05 & 25.57 & 25.66 & 20.06 & 29.85 & 32.13 \\
\hline $\begin{array}{l}\text { MUSFA } \\
\text { / PUSFA }\end{array}$ & 5.88 & 8.27 & 1.78 & 1.96 & 2.04 & 2.99 & 1.72 & 1.58 \\
\hline
\end{tabular}

$\mathrm{Nd}=$ not detected

The same results revealed that, Arbequina VOO showed the highest mean value for SFA (20.7), while Koroniki VOO showed the highest mean value for MUSFA (70.62\%) and lowest PUFA (10.44\%).

The MUSFA / PUSFA were also different among the oils, CV No.138 and Arbequina VOO had the lowest mean value (1.65 and 1.87, respectively) and Koroniki had the highest mean value (7.07). In Siwi and Coratina VOOs, the values were intermediate (6.46, 6.08 and 4.80, 4.55 for the ratios C18:1/ C18:2 and MUSFA / PUSFA, respectively) Eid et. al., 2012. The MUSFA/PUSFA ratio is frequently used as a stability parameter and, in previous studies, the cultivars with higher ratios were those with higher oxidative stability (Beltran, 2000). Koroniki and cV No.1 VOOs had the highest average values for (7.07 and 2.51, respectively) in accordance with their higher oxidative stability indices. $c v$ No.138 had the lowest ratio 1.65 but, it had a high mean oxidative stability (15.69 hr) than Arbequina cultivar 11.39 hr Table 2). 
This is due to the fact that oxidative stability is related not only to fatty-acid composition, but also to several other factors, pro- and/or anti-oxidant substances and concentration of natural antioxidants, such as polyphenols, in the oil (Ceci and Carelli., 2007). In fact, this sample had the highest mean values for phenols and atocopherols content.

\section{Sterols composition}

Sterols are major constituents of the unsaponifiable fraction. The sterol composition is very important in the evaluation of the nutritional value, but also in the quality control of olive oils, since it can be used to detect adulteration. Also, they are important components for the stability of the oil since at high temperature they act as inhibitors of polymerization reactions (Velasco \& Dobarganes, 2002). The obtained results of sterols profile for korniki cultivar which, is meet the accepted range of fatty acids profile in the two seasons according to IOC, 2011 are determined and displayed in Table (4).

The predominant sterols in Koroniki variety olive oil were $\beta$-sitosterol (82.10 and $83.33 \%$ at the $1^{\text {st }}$ and $2^{\text {nd }}$ seasons, respectively), $\Delta$-5-avenasterol( 6.10 and $6.14 \%$ at the $1^{\text {st }}$ and $2^{\text {nd }}$ seasons, respectively ) Campesterol (2.88 and $2.91 \%$ at the $1^{\text {st }}$ and $2^{\text {nd }}$ seasons, respectively). The sterols composition of these components was slightly increased at the second season.The results of Eid et al.,2012 for Koroniki cultivar which cultivated in Giza zone were close to our findings and it was $83.63 \%$ for $\beta$ - sitosterol and $50.63 \%$ for Arbequina cultivar. Moreover, the contents of apparent $\beta$-sitosterol was more than $93 \%$ in the two seasons which met the IOC, 2011 and also for all sterols components.

Table 4. Sterols and Unsaponifiable matter (\%) of Koroniki cultivar duringtwo successive seasons

\begin{tabular}{|c|c|c|}
\hline \multirow{2}{*}{ Sterols (\%) } & \multicolumn{2}{|c|}{ Koroniki } \\
\cline { 2 - 3 } & $2010 / 2011$ & $2011 / 2012$ \\
\hline Cholesterol & 0.11 & 0.30 \\
\hline Campesterol & 2.88 & 2.91 \\
\hline Stigmasterol & 0.40 & 0.63 \\
\hline$\beta$-sitosterol & 82.10 & 83.33 \\
\hline$\Delta$-5-avenasterol & 6.10 & 6.14 \\
\hline$\Delta$-7-stigmastenol & 0.24 & 0.44 \\
\hline Others & 8.17 & 6.25 \\
\hline Campesterol / Stigmasterol & 7.20 & 4.61 \\
\hline Unsaponifiable matter (\%) & 1.21 & 1.24 \\
\hline
\end{tabular}


The unsaponifiable matter (\%) of Koroniki olive oil represented 1.21 and 1.24 at the $1^{\text {st }}$ and $2^{\text {nd }}$ seasons, respectively. The percent of unsaponifaible matter also, slightly increased at the second seasons. The composition of the unsaponifiable fraction of VOO is affected by several factors such as olive cultivar, altitude, climatology, agronomic factors, time of harvest, and olive storage after harvest and oil extraction system.

Finally, it can be concluded that through the characterization of different olive oil cultivars under investigation in El-Khatatba zone that, all the analysed VOOs were classified into "Extra virgin" category according to the regulated physicochemical parameters, but only Koroniki cultivar is complied with IOC, 2011(Trade Standard for Olive Oil) during evaluation period.

If the fatty acid and sterols compositions were also taken into account Arbequina and new cultivar No.1 or No.138 virgin olive oils were stood out of IOC limits during evaluation period due to its non-compliance in fatty acid composition.

It is recommended for the new cultivars to do more evaluation for many seasons also, in different zone areas to enhancement the fatty acid profile or to ensure the stability of fatty acids profile and chemical compositions which agree with the olive oil international standards to increase the competitiveness of Egyptian olive oil in international markets. The study was emphasized that, the minor components, fatty acids and sterol compositions are mainly affected by olive cultivars (genotype) and climatic conditions.

\section{REFERENCES}

1. Alfonso, M.B., Owen, J., 2002. Alternative methods for controlling the olive fly, Bactrocera oleae, ivolving semiochemicals. Use of pheromones and other semi chemicals in integrated production. IOBC wprs Bulletin 25.

2. A.O.A.C., 2005. Official Methods of Analysis, Vol. II, 16th Edition, Virginia 22201, Arlington.

3. Baccouri, B., Ben Temime, S., Taamalli, W., Daoud, D., M'sallem,M., Zarrouk, M., 2007. Analytical characteristics of virgin olive oils from two new varieties obtained by controlled crossing on Meski variety. J. Food Lipids 14, 19-34.

4. Beltran, G. 2000. Influence of Ripening Process in Olea europaea L. Fruits on the Physicochemical Characteristics of the Oils. Ph.D. Thesis, Universidad de Jaen, Spain. 
5. Basuny, M.A., Arafat, M.S. and Mostafa, M.D. 2008. Virgin olive oil quality: Relationship between bioactive components and organoleptic evaluation. Alex. J. Fd. Sci.\& Tech. 3: 21-29.

6. Bortolomeazzi, R., Berno, P., Pizzale, L., \& Conte, L. S. 2001. Sesquiterpene, alkene, and alkane hydrocarbons in virgin olive oils of different varieties and geographical origins. Journal of Agricultural and Food Chemistry, 49(7), 32783283.

7. Canabate-Diaz, B., Segura Carretero, A., Fernandez-Gutierrez, A., Belmonte Vega, A., Garrido Frenich, A., Martinez Vidal, J. L., et al. 2007. Separation and determination of sterols in olive oil by HPLC-MS. Food Chemistry, 102(3), 593598.

8. Ceci , L. N. and Carelli, A. A.. 2007. Characterization of Monovarietal Argentinian Olive Oils from New Productive Zones. J Am Oil Chem Soc (2007) 84:1125-1136.

9. Cercaci, L., Passalacqua, G., Poerio, A., Rodriguez-Estrada, M. T.,\&Lercker, G. 2007. Composition of total sterols (4-desmethyl-sterols) in extravirgin olive oils obtained with different extraction technologies and their influence on the oil oxidative stability. Food Chemistry, 102, 66-76.

10. Cossiganani, L., Simonetti, M.S. and Damiani, P. 2005. Biocatalyzed acidolysis of olive oil triacylglycerols with 9c,11t and 10t,12c isomers of conjugated linoleic acid Eur. Food Res. Technol., 220, 267-271 (2005).

11. Dabbous, S, Rjiba,I. , Nakbi, A., Gazzah,N., Issaoui,M. and Hammami, M. 2010.Compositional quality of virgin olive oils from cultivars introduced in Tunisia aird zones in comparison to /chemlali cultivars. 26:122-127.

12. Dag, A., Ben-David, E.A., Fiume, P., Perri, E. 2009. Cultivation: Problems and Perspectives, Sixth Framework Programme Priority 5, Food Quality and Safety Priority, Call 4-C, MAC-oils. The Scientific Handbook, Avellino, Italy, pp. 1-55.

13. EEC 1991. Characteristic of olive and olive pomace oils and their analytical methods. Regulation EEC/2568/91 and later modification. Official Journal of European Communities, L248, 1-82.

14. Eid, M.M. and El-Sorrady,M.E.I. 2012.Sterols composition of some olive oil varieties cultivated under Egyptian Conditions. Egypt. J. Agric. Res., 90 (1), 263276.

15. Gamez-Meza, N., Nriega-Rodiguez, T. A., Medira-Jularz, L. A., Ortega-Gracia, J., Cazarazez-Casanova, R., and Angulo-Guerrero, O. 1999. Antioxidant activity in soybean oil of extracts from Thompson grape bagasse. JAOCS, 76, 1445-1447. 
16. Gutierrez, F., Villafranca, M.Jj. and Castellano, J.M. 2002. Changes in the main components and quality indices of virgin olive oil during oxidation. J. Am Oil. Chem. Sco., 79, (7), 669-676.

17. Ibaneza, E., Andres, M. Hurtado Benavides, Francisco J. Senorans, and Guillermo Regleroc. 2002. Concentration of Sterols and Tocopherols from Olive Oil with Supercritical Carbon Dioxide. JAOCS, Vol. 79, no. 12 pp.1255-1260.

18. IOC, 2011. Trad standard applying to olive oils and olive-pomace oils. COI/T.15/NC No 3/Rev. 5. November, 2010

19. Kiritsakis, A.K. 1998. Olive Oil Handbook. AOCS Press, Champaign, IL.

20. Koprivnjak,O., Skevin,D., Petricevic,S. , Bubola,K.B. and Mokrowvcak,Z. 2009. Bitterness, odor properties and volatile compounds of virgin olive oil with phospholipids addition.LWT Food Sci. \& Tech. 42,(1), 50-55.

21. Lazzez, A., Perri, E., Caravita, M.A., Khlif, M., Cossentini, M., 2008. Influence of olive maturity stage and geographical origin on some minor components in virgin olive oil of the Chemlali Variety. J. Agric. Food Chem. 56 (3), 982-988.

22. Lopez-feria,S., Cardenenas,S., Gacia-Mesa,J.A. and Valcarecel,M. 2008. Classification of extra virgin olive oils according to the protected designation of origin, olive oil variety and geographical origin . Tatanta, 75:937-943.

23. Menz, G., Vriesekoop, F. 2010. Physical and chemical changes during the maturation of Gordal Sevillana olives (Olea europaea L., CV. Gordal Sevillana). J. Agric. Food Chem. 58, 4934-4938.

24. Minguez-Mosqueera, M.I., Rejano, L., Gandul, B. , Sanchez, A. H. and Garrido, J. 1991. Color-Pigment correlation in virgin olive oil.J. Am. Oil Chem. Sco., 86: 322337.

25. Szterk, A. , Roszko, M., Sosinska, E., Derewiaka,D., Lewicki,P.P. 2010. Chemical composition and oxidative stability of selected plant oils. J Am Oil Chem Soc (87:637-645).

26. Velasco, J. and Dobarganes, C. 2002. Oxidative stability of virgin olive oil, Eur. J. Lipid Sci. Tech., 104:661-679.

27. Visioli, F., \& Galli, C. 2002. Biological properties of olive oil phytochemicals. Critical Reviews in Food Science and Nutrition, 42(3), 209-221.

28. Wong, M. I., Timms, R. E. and Goh, E. M. 1991. Colorimetric determination of total tocopherols in Palm oil, Olein and Stearin. JAOCS., 65, (2), 259-262. 


\title{
خصائص بعض اصناف زيتون الزيت الجديدة المنزرعة فى منطقة الخطاطبة - مصر
}

\author{
منير محمد عيد1 1 \\ ا ـ قسم بحوث الزيوت و الدهون- معهد بحوث تكنولوجيا الأغذية- مركز البحوث الزراعية - الجبزة

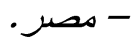 \\ r ـ قسم الزيتون وفاكهة الدناطق النصف جافة- معهُ بحوث البساتين- مركز البحوث الزرراعية-

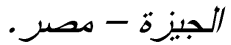

يهذف هذا البحث إلى التعرف على خصائص زيت الزيتون البكر لإربعة اصناف زيتون

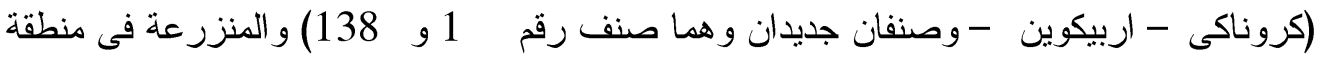

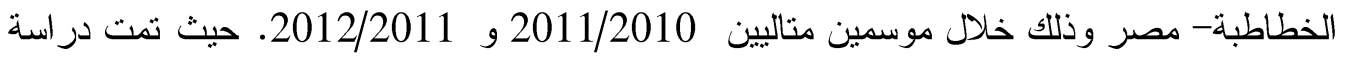
خصائص الجودة ( الحموضة ، و رقم البيروكسيد ، K232 ، K270 ، KK ) ، مؤشر الثبات

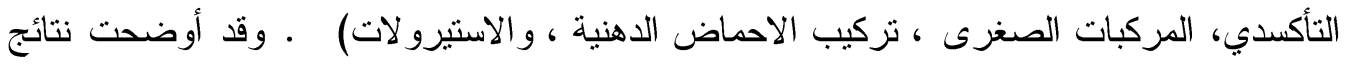
خصائص الجودة ان جميع الزيوت للأصناف المحلة تعتبر "Extra virgin" طبقا لمقاييس الجودة ،

كما اوضحت النتائج ان زيت الزينون لصنف الكروناكى هو الوحيد المطابق للمو اصفة التجارية للمجلس الدولى لزيت الزيتون سنة 2011 خلال الموسميين من ناحية تركيب الأحماض الدهنية ومحتوى الأستيرو لات له ، علاوة على انه كان اعلى الأصناف من ناحية الثبات الأكسيدى خلال لرل لرل الموسميين (24.81 و 26.5 ساعة على التو الى) بينما صنف اربيكوين كان اقلها (9.8 و 12.99 ساعة على التو الى) ويرجع ذلك لنسبة المركبات الصغرى (البولى فينو لات، الفا-توكوفيرول ،

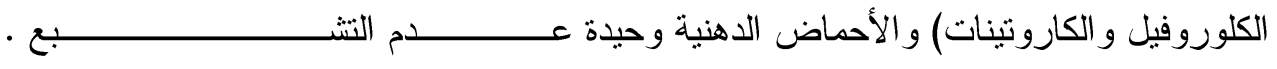

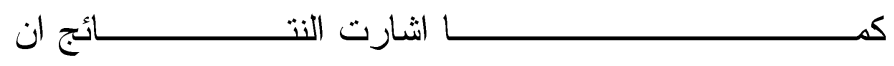

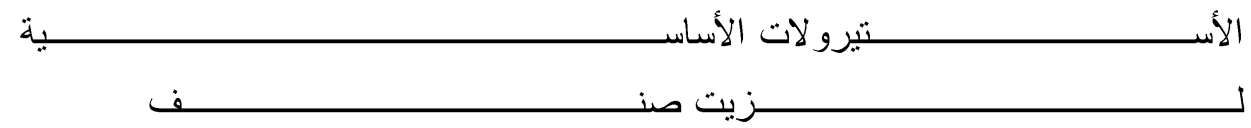

الكروناكـــsitosterol م- ( 82.10 و 83.33 \% للموسم

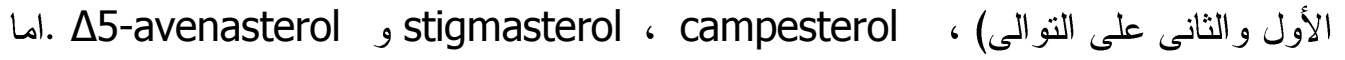
بالنسبة للاصناف الجديدة صنف 1 أو 138 فكانت اعلى الأصناف فى نسبة الزيت 20.25 و 18.75

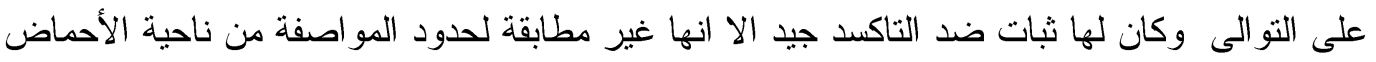
الدهنية خلال الموسميين ، هذا وقد اشارت النتائج ان تركيب المركبات الصغرى ، الأندان الأحماض الدهنية و الأستيرو لات يرجع اساسا الى الصنف و الظروف المناخية المحيطة. 